\section{Mr. R. H. Burne, F.R.S.}

THE retirement of Mr. R. H. Burne from the physiological curatorship of the Royal College of Surgeons' Museum was marked by a complimentary dinner which was held in his honour at the Langham Hotel on May 10. Among those present were Sir Holburt Waring, Sir Cuthbert Wallace, Sir Arthur Keith, Sir Arthur Smith Woodward, Sir Peter Chalmers Mitchell, Dr. Tate Regan, Sir Charles Ballance, Prof. E. Barclay-Smith, Prof. William Wright, Sir Buckston Browne, Prof. E. S. Goodrich and Mr. C. Forster-Cooper. Mr. Burne's contributions to zoological and anatomical literature have been outstanding in that they have been the result of painstaking dissection of the most intricate kind. The physiological series of the Royal College of Surgeons contains innumerable examples of his masterful skill with the scalpel. Many of these preparations illustrate discoveries which he has himself made, but has never published. His election to the fellowship of the Royal Society in 1927 was the recognition of his scientific work in the College Museum. The complimentary dinner was in its turn a mark of appreciation by his friends of his modest and retiring personality.

\section{Television Committee}

The Postmaster-General announced in the House of Commons on May 14 that the Television Com. mittee is to be constituted as follows:-Lord Selsdon (chairman); Sir John Cadman (vice-chairman); Col. A. S. Angwin, Assistant Engineer-in-Chief, G.P.O. ; Mr. Noel Ashbridge, Chief Engineer, B.B.C.; Mr. O. F. Brown, Department of Scientific and Industrial Research; Vice-Admiral Sir Charles Carpendale, Controller, B.B.C. ; Mr. F. W. Phillips, Assistant Secretary, G.P.O. The secretary of the Committee is Mr. J. Varley Roberts, Telegraph and Telephone Department, G.P.O., E.C.1, and the terms of reference are : "To consider the development of television and to advise the Postmaster-General on the relative merits of the several systems and on the conditions under which any public service of television should be provided."

IT does not appear that any of the members of the Committee appointed by the Postmaster-General have that practical knowledge of the scientific problems involved in television desirable for the consideration of the position and possible development of the subject. It will be difficult, therefore, for the Committee to estimate with authority the value of the various systems which have been developed. Even in regard to the commercial interests involved, and the attempts made in other countries to popularise television, the Committee will have mainly to depend upon the experience or knowledge of others. Moreover, since the relative merits of the systems of television to be examined may have to be decided on patent issues, it is strange that no member of the Committee familiar with patent law and practice has been appointed. It seems, therefore, that the Committee will have to base its report upon evidence given by the various television interests; and we suggest that it would have been better if the Postmaster-General had convened a conference of these interests and asked them to present an agreed report on the two main questions submitted to the Committee he has appointed. He might thus have had the fullest technical information on television presented to him direct by the companies who command the services of all the television experts available. As it is, the Committee will have a difficult task in securing such information and assessing its value; and whatever report is issued is likely to be challenged by companies concerned with the development of television.

\section{Plague of Blood-sucking Flies in Yugoslavia}

WE learn from the Times of May 12 that an insect plague is causing serious trouble in parts of Yugoslavia. The insect in question is referred to as the 'golubatz fly', which has recently appeared in parts of the country not previously troubled by the pest. Several peasants and some 500 cattle and sheep have already perished. A poisonous fluid injected by the fly has the effect of breaking down the red blood corpuscles, so that when the 'bites' become numerous death may supervene. From the account given, it is evident that the fly in question is a species of Simulium or buffalo gnat. This genus comprises blood-sucking flies which are troublesome pests in several parts of the world. In regions bordering on the Danube the species $S$. columbaczense, which is most probably the fly involved in the present outbreak, causes at times heavy mortality, especially among horses, as the result of its blood-sucking propensities. Its larvæ and pupæ live in streams and rivers while the adult flies sometimes occur in immense swarms. In 1923, an invasion in Rumania is computed to have caused a loss to farmers of about

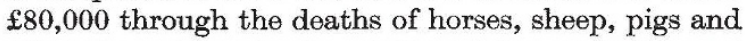
other domestic animals. Although human beings are also attacked and severely bitten, fatal cases seem to occur but seldom. In their efforts to control the plague, the farmers used smoke screens and applied various repellent smears to their stock. Much the same methods are being used in the present outbreak, the peasants lighting bonfires in order to protect their stock, the herds being kept indoors during the day and allowed to graze only between sunset and sunrise. A feature of such outbreaks is that the flies may be carried long distances by the wind, with the consequent invasion of areas where the farmers have no previous experience in applying control measures.

\section{Dust Clouds in the United States}

A RARE meteorological phenomenon was experienced in New York on May 11, when a cloud of grey dust enveloped that city. This cloud of dust is described as having reached the eastern seaboard of the United States early on that day, and is said to have extended from New England down to Washington, to have been denser in the Middle West and to have measured 1,500 miles by 900 miles in the horizontal and about three miles in the vertical. 
The damage and discomfort caused by the dust was evidently very great. A synoptic weather chart for that day prepared in the Meteorological Office, Air Ministry, from wireless weather bulletins, supports the suggestion made in the Times that the dust was carried by the wind from a region in Western Canada and the neighbouring States which is suffering from severe drought, for a vigorous circulation of wind around a deep cyclonic depression is shown on the chart, and this circulation is in about the expected position. Aeroplanes are said to have encountered the dust cloud, the pilots having estimated that it was travelling eastwards at speeds between 60 miles and 100 miles an hour. The phenomenon can safely be compared in its origin with the dust storms of Egypt and Northern India; a fall of red rain in London due to a circulation of wind round an anticyclone, which brought down dust from the Sahara -investigated many years ago by Shaw and Lempfert -was essentially similar in character. It appears to be one of the attendant evils of North American droughts that fine tilth can be removed from its proper place in the farmers' fields and be deposited in distant States where its presence-even in agricultural country-is far from being immediately beneficial.

\section{Centenary of Liverpool Medical School}

ON May 11, the University of Liverpool celebrated the centenary of the Liverpool Medical School. In connexion with the celebrations, a brief illustrated account of the School by Arthur A. Gemmell has been issued ("The Liverpool Medical School, 1834-1934". Hodder and Stoughton, Ltd., London. 1s.). On the occasion of the conferment of honorary degrees to celebrate the foundation of the School, an address was delivered by Prof. John Hay, professor of medicine in the University. Until 1821, St. Bartholomew's, St. Thomas's, Guy's and the London Hospitals held the monopoly of medical teaching; then the barrier against provincial teaching was broken down by the Society of Apothecaries in recognising the teaching of Dr. Joseph Jordan in Manchester. In 1824, the clinical teaching at the Manchester Infirmary School was recognised; thus Manchester was the first provincial medical school in England. Undoubtedly the efforts of the Manchester medical men were a stimulus to those in Liverpool. Anatomy schools were developed first, and finally a School of Medicine. In 1837, the School was recognised by the London Society of Apothecaries, the College of Surgeons, and the University of London. In 1884, it was incorporated with University College when the latter, which was founded in 1881 , was admitted into Victoria University. In 1903, when the University of Liverpool was granted its charter, the School became its Faculty of Medicine. Among the distinguished occupants of the endowed chairs in the past have been Lodge, Campbell Brown, Herdman, Gotch, Paterson, Boyce, Sherrington, Benjamin Moore and Ronald Ross.

Associated with the School of Medicine at Liverpool is the School of Tropical Medicine, with seats on the
Faculty of Medicine. This School was founded in 1899, and has the distinction of being the first of its kind in the world. In 1921, the School established a permanent laboratory at Freetown, Sierra Leone, and already has a brilliant record of studies in malaria, yellow fever, sleeping sickness, blackwater fever, vomiting fever, as well as entomology, helminthology and tropical sanitation. At the celebrations, the honorary degree of D.Sc. was conferred on Prof. H. R. Dean, professor of pathology in the University of Cambridge; Sir Thomas Lewis, physician, University College Hospital; Mrs. May Mellanby, investigator for the Medical Research Council ; Wilfred Trotter, Sergeant Surgeon to the King ; and LL.D. on Prof. William Blair-Bell, emeritus professor of obstetrics and gynæcology in the University; Prof. H. Briggs, emeritus professor of obstetrics and gynæcology in the University; Herbert R. Hurter, Liverpool, past president of the Liverpool Medical Institution ; W. S. Paget-Tomlinson, lately chairman of the Public Health Committee of Westmorland; Prof. Charles H. Reilly, emeritus professor of architecture in the University of Liverpool.

\section{Excavations at Ur, I933-34}

DR. C. L. Woolley's lecture on "The Year's Work at Ur", given at the Royal Institution on May 11, afforded his audience a more favourable opportunity of appraising the results of this brief season's excavations than has been possible from the summary reports which have appeared in the Press. The elucidation and study of the earlier phases of the occupation of the site have been carried down through pre-flood strata to the bottom of the marsh before man appears on the scene. The history of the ziggurat, dating in its present form from 2300 B.C., of the attendant temples of the First Dynasty (3000 B.c.) and of the antecedent buildings which they replaced, has been brought back to the very beginning of the 'plano-convex' period, while beneath have been found still earlier periods of which the later must belong to the 'Jemdet Nasr' age. It was not possible at this point in the excavation area to carry the work to its logical conclusion by deeper digging; but Dr. Woolley traced the course of excavations at the south-eastern end of the Temenos area from the modern ground-level right down to virgin soil, through deposits of the age of Nebuchadnezzar, the Kassite age (1400-1000 B.c.), the Sargonid period (2600 B.c.) and through a continuation of the Royal Cemeteries of the fourth millennium. It was at this point, in what was evidently a soldiers' burial ground, that the unique discovery of a female statue deposited as a funerary offering was made. Below this were the archaic written tablets and seal impressions and at a still greater depth the graves, extending over a considerable period of time, which have proved so amazingly rich in stone vases of varied form and material. In the mixed soil in which, as well as in the sandy flood deposit, were found the earlier graves yielding Jemdet Nasr ware, there were abundant sherds of $\mathrm{Al}$ 'Ubaid ware, thus completing a remarkable record which covers the complete range of Mesopotamian history from the middle of the first 